\title{
Influence of Nitrogen and Weed Management Practices on Growth and Yield of Direct Seeded Rice (Oryza sativa L.)
}

\author{
Bonu Rama Devi* and Yashwant Singh \\ Department of Agronomy, Institute of Agricultural Sciences, Banaras Hindu University, \\ Varanasi-221 005, India \\ *Corresponding author
}

\begin{tabular}{|l|}
\hline Ke y w o r d s \\
Direct seeded rice, \\
$\begin{array}{l}\text { Nitrogen, Weed } \\
\text { management, Yield, } \\
\text { Weed }\end{array}$ \\
\hline Article Info \\
\hline $\begin{array}{l}\text { Accepted: } \\
\text { 20 December } 2017 \\
\text { Available Online: } \\
\text { 10 January } 2018\end{array}$ \\
\hline
\end{tabular}

A B S T R A C T

A field experiment was conducted during rainy (kharif) season of 2015 and 2016 to study the effect of nitrogen and weed management in direct seeded rice (Oryza sativa L.) Nitrogen management significantly reduced the population of grasses, sedges and broad leaved weeds and increased weed control efficiency and increased growth attributes and yield of crop. The results indicated that the minimum population of grasses, sedges and broad leaved weeds, weed dry weight and maximum weed control efficiency and maximum crop growth attributes and yield was recorded with the application of $1 / 4 \mathrm{~N}$ basal $+1 / 4 \mathrm{~N}$ at active tillering stage $+1 / 4 \mathrm{~N}$ at panicle initiation stage $+1 / 4 \mathrm{~N}$ at heading stage. Application of $1 / 2 \mathrm{~N}$ basal $+1 / 4 \mathrm{~N}$ at active tillering stage $+1 / 4 \mathrm{~N}$ at panicle initiation stage recorded higher population of grasses, sedges and broad leaved weeds and dry weight during both the years. The various weed management treatments significantly decreased the population and dry weight of weed and increased the weed control efficiency, crop growth characters and yield when compared with the weedy check. Two hand weedings at 20 and 40 DAS and bispyribac at $25 \mathrm{~g}$ a.i. $\mathrm{ha}^{-1}+$ azimsulfuron at $17.5 \mathrm{~g}$ a.i. ha ${ }^{-1}+$ NIS $(0.25 \%)$ at $15-20$ DAS recorded minimum weed population and dry weight of weed and increased the weed control efficiency, crop growth characters and yield of the crop when compared to other treatments.

\section{Introduction}

Rice is a staple food for more than half of the world population, is commonly grown by transplanting seedlings into puddled soil in Asia. This production system is labor, water, and energy-intensive and is becoming less profitable as these resources are becoming increasingly scarce. It also deteriorates the physical properties of soil, adversely affects the performance of succeeding upland crops, and contributes to methane emissions. These factors demand a major shift from puddled transplanting to direct seeding of rice (DSR) in irrigated rice ecosystems.

Direct seeding of rice in the Indo-Gangetic plains has begun and farmers are finding the new technology attractive. The productivity of the DSR was on a par with transplanting and the net profit was higher. In spite of the weed menace, farmers in eastern U.P. and Bihar opt 
for dry-DSR when it is difficult for them to complete rice transplanting in time or water supplies are uncontrolled such as low or upland rice ecologies (Singh et al., 2010). Nitrogen is a key nutrient in determining the level of crop productivity. The efficiency of applied nitrogen is very low and varies from 20 to $25 \%$ in upland rice crop due to the oxidized condition prevailing in uplands and concomitant heavy nitrogen loss through percolating water. Hence, fractional application of nitrogen in right amount and proportion, and when it is needed the most seems to be a practical proposition. Weed is one of the major constraints for low productivity of upland rice (Angiras, 2002). In direct-seeded upland rice, weeds pose serious competition to the crop in early stage and cause heavy reduction in rice yield. Uncontrolled weeds reduce the yield up to $80 \%$ in direct-seeded upland rice. Weed control also facilitates higher absorption of applied nutrient, thus increases the efficiency of fertilizers application to the crops (Amarjit et al., 2006). Manual and mechanical methods are not effective in controlling sedges and broad-leaved weeds in direct-seeded rice because of the high labour cost, scarcity of labour during the critical period of weed competition and unfavorable weather at weeding time. Hence usage of herbicides is becoming increasingly popular as a viable alternative to hand weeding. To avoid undesirable weed shift and herbicide resistance in weeds, the continuous use of herbicides with similar mode of action has to be restricted. But in spite of the usage of all such herbicidal combinations, control failures, lot of escapes or regeneration in some of the weed species have been recently noticed in DSR at many locations. Therefore, considering the emergence of diverse weed types in rainy (kharif) season, the purpose cannot be solved by one-time application of herbicide alone. Considering these problems, we have to apply several herbicides in combination or in sequence, other than the already used combinations, which can provide more useful solution in controlling complex and diverse weed flora in DSR (Raj et al., 2013). Fractional application of nitrogen in right amount and proportion coupled with weed control practices facilitates higher absorption of applied nitrogen and thus increasing efficiency of fertilizer nitrogen.

\section{Materials and Methods}

A field experiment was conducted during rainy (kharif) season of 2015 and 2016 at Agricultural Research Farm, Department of Agronomy, Institute of Agricultural sciences, Banaras Hindu University, Varanasi, Uttar Pradesh. The soil was Gangetic alluvial having Sandy clay loam in texture with $\mathrm{pH}$ 7.60. It was moderately fertile, being low in available organic carbon $(0.40 \%)$, available $\mathrm{N}$ (198.38 $\left.\mathrm{kgha}^{-1}\right)$, and medium in available $\mathrm{P}$ (17.78 $\mathrm{kg} \mathrm{ha}^{-1}$ ) and $\mathrm{K}\left(216.32 \mathrm{~kg} \mathrm{ha}^{-1}\right)$. The experiment was laid out in split-plot design with three replications. The nitrogen management subjected to main plots while weed management in sub plots. A combination of 24 treatments consisting of 4 nitrogen management, viz. $\mathrm{N}_{1}-1 / 2 \mathrm{~N}$ basal $+1 / 4$ $\mathrm{N}$ at active tillering stage $+1 / 4 \mathrm{~N}$ at panicle initiation stage, $\mathrm{N}_{2}-1 / 4 \mathrm{~N}$ at basal $+1 / 2 \mathrm{~N}$ at active tillering stage $+1 / 4 \mathrm{~N}$ at panicle initiation stage, $\mathrm{N}_{3}-1 / 3 \mathrm{~N}$ at basal $+1 / 3 \mathrm{~N}$ at active tillering stage $+1 / 3 \mathrm{~N}$ at panicle initiation stage and $\mathrm{N}_{4}-1 / 4 \mathrm{~N}$ basal $+1 / 4 \mathrm{~N}$ at active tillering stage $+1 / 4 \mathrm{~N}$ at panicle initiation stage $+1 / 4 \mathrm{~N}$ at heading stage and 6 weed management treatments, viz. $\mathrm{W}_{0}$ Weedy check, $\mathrm{W}_{1^{-}}$Two hand weedings at 20 and 40 DAS, $W_{2}$ - Pendimethalin $1.0 \mathrm{~kg}$ a.i ha ${ }^{-}$ ${ }^{1}$ (PE) fb Bispyribac at $25 \mathrm{~g}$ a.i $\mathrm{ha}^{-1}+$ NIS $(0.25 \%)$ at $15-20 \mathrm{DAS}, \mathrm{W}_{3}-$ Bispyribac at 25 $\mathrm{g}$ a.i. $\mathrm{ha}^{-1}+$ Pyrazosulfuron at $20 \mathrm{~g}$ a.i. $\mathrm{ha}^{-1}+$ NIS $(0.25 \%)$ at $15-20$ DAS, $\mathrm{W}_{4}$ - Oxadiargyl at $90 \mathrm{~g}$ a.i. $\mathrm{ha}^{-1}(\mathrm{PE}) \mathrm{fb}$ Bispyribac at $25 \mathrm{~g}$ a.i. $\mathrm{ha}^{-1}+\mathrm{NIS}(0.25 \%)$ at $15-20$ DAS and $\mathrm{W}_{5}-$ 
Bispyribac at $25 \mathrm{~g}$ a.i. $\mathrm{ha}^{-1}+$ Azimsulfuron at 17.5 g a.i. ha $\left.^{-1}\right)+$ NIS $(0.25 \%)$ at 15-20 DAS. A uniform dose of $150 \mathrm{~kg} \mathrm{~N}^{-1}, 60 \mathrm{~kg} \mathrm{P}_{2} \mathrm{O}_{5}$ $\mathrm{ha}^{-1}$ and $60 \mathrm{~kg} \mathrm{~K}_{2} \mathrm{O} \mathrm{ha}^{-1}$ were applied in all the plots. Full dose of phosphorus and potash were applied as basal application and nitrogen was applied as treatment wise. 'HUR 105' variety of rice@ $35 \mathrm{~kg} \mathrm{ha}^{-1}$ was used for seeding of rice. The total rainfall received during crop season was 871.5 and 1187.8 during first and second year, respectively. Although distribution of rainfall was less in first year but they are uniform as compared to second year in crop period. The required quantity of pre-emergence and postemergence herbicides was sprayed as per treatment using spray volume of 600 litres of water ha ${ }^{-1}$ with the help of knap sack sprayer fitted with flat fan nozzle. The data on weeds were subjected to square-root transformation $(\sqrt{x+0.5})$ to normalize their distribution.

\section{Results and Discussion}

\section{Effect on weed}

Grassy weeds were predominant in DSR followed by sedges and broad leaved weeds, respectively. The dominant weed species observed in the experimental field were Echinocloa crus-galli, Echinocloa colona, Cynodon dactylon, Cyperus rotundus, Cyperus iria, Eclipta alba and Caesulia axillaris during both the years of study.

\section{Weed population}

Among various nitrogen management treatments, nitrogen application of $1 / 4 \mathrm{~N}$ at basal $+1 / 4 \mathrm{~N}$ at active tillering stage $+1 / 4 \mathrm{~N}$ at panicle initiation stage $+1 / 4 \mathrm{~N}$ at heading stage was the most effective in reduced population of grasses, sedges and broad leaved weeds (No. $\mathrm{m}^{-2}$ ) at 60 DAS and recorded significantly lower weed population and was comparable to $\mathrm{N}_{3}-1 / 3 \mathrm{~N}$ at basal $+1 / 3 \mathrm{~N}$ at active tillering stage $+1 / 3 \mathrm{~N}$ at panicle initiation stage (Table 1). Nitrogen application of $1 / 2 \mathrm{~N}$ basal $+1 / 4 \mathrm{~N}$ at active tillering stage + $1 / 4 \mathrm{~N}$ at panicle initiation stage recorded significantly maximum weed population at 60 DAS during both the years of study. This might be due to the fact that treatments in which equal amounts of nitrogen were applied with more number of splits at critical growth stages. These results are in conformity with the findings of Chaudhary et al., (2011).

All the weed management practices showed significant effect on weeds and had less weed growth as compared to weedy check which recorded maximum weed population. Among the weed management treatments, two hand weedings at 20 and 40 DAS and application of bispyribac at $25 \mathrm{~g}$ a.i. $\mathrm{ha}^{-1}+$ azimsulfuron at $17.5 \mathrm{~g}$ a.i. $\mathrm{ha}^{-1}+$ NIS $(0.25 \%)$ at $15-20$ DAS were more efficient in minimizing weed infestation and weed growth than other weed management treatments followed by bispyribac at $25 \mathrm{~g}$ a.i. $\mathrm{ha}^{-1}+$ pyrazosulfuron at $20 \mathrm{~g}$ a.i. $\mathrm{ha}^{-1}+\mathrm{NIS}(0.25 \%)$ at 15-20 DAS. Application of oxadiargyl at $90 \mathrm{~g}$ a.i. $\mathrm{ha}^{-1}(\mathrm{PE})$ $f b$ bispyribac at $25 \mathrm{~g}$ a.i. $\mathrm{ha}^{-1}+\mathrm{NIS}(0.25 \%)$ at 15-20 DAS had minimum efficacy in these respect during both the years of study. This might be due to tank mix application for controlling diverse group of weeds at a time in direct seeded condition. The tank mix application of such suitable herbicides performed better against diverse weed flora as compared to application of a single herbicide. These findings may be supported by Kumar et al., (2013).

\section{Weed dry weight}

Total weed dry weight was significantly influenced by different nitrogen and weed management practices. Application of $1 / 4 \mathrm{~N}$ at basal $+1 / 4 \mathrm{~N}$ at active tillering stage $+1 / 4 \mathrm{~N}$ at panicle initiation stage $+1 / 4 \mathrm{~N}$ at heading stage recorded minimum weed dry weight and the 
maximum weed dry weight was recorded with the application of $1 / 2 \mathrm{~N}$ basal $+1 / 4 \mathrm{~N}$ at active tillering stage $+1 / 4 \mathrm{~N}$ at panicle initiation stage (Table 1). This might be due to the fact that application of less amount of nitrogen at the time of sowing or with in the month of crop growth from sowing reduces the weed population by reducing the availability of nitrogen to the weed germination and for the growth of the weeds, so that adversely affected the growth and development of weeds in direct seeded rice. These findings are similar with the results reported by Singh and Singh (2007).

Among weed management practices, minimum total weed dry weight was recorded under two hand weedings at 20 and 40 DAS followed by bispyribac at $25 \mathrm{~g}$ a.i. $\mathrm{ha}^{-1}+$ azimsulfuron at $17.5 \mathrm{~g}$ a.i. $\mathrm{ha}^{-1}+\mathrm{NIS}(0.25 \%)$ at 15-20 DAS. The next best treatment was bispyribac at $25 \mathrm{~g}$ a.i. $\mathrm{ha}^{-1}+$ pyrazosulfuron at $20 \mathrm{~g}$ a.i. $\mathrm{ha}^{-1}+$ NIS $(0.25 \%)$ at 15-20 DAS. The reason behind this integration of pre- and post-emergence herbicides minimized the weed dry weight. Wallia et al., (2008) reported that integration of pre-emergence application of pendimethalin followed by post emergence of azimsulfuron resulted in effective weed control. The maximum weed dry weight recorded in weedy plots in respect to other treatment.

\section{Weed control efficiency}

Weed control efficiency indicates the relative efficacy of weed management practices over weedy check. Under different nitrogen treatments, nitrogen application of $1 / 4 \mathrm{~N}$ at basal $+1 / 4$ at active tillering stage $+1 / 4 \mathrm{~N}$ at panicle initiation stage $+1 / 4$ at heading stage recorded highest weed control efficiency due to lower dry matter accumulation of weeds at all the stages of crop growth during both the years of study (Table 1). This was followed by $1 / 3 \mathrm{~N}$ at basal $+1 / 3 \mathrm{~N}$ at active tillering stage
$+1 / 3 \mathrm{~N}$ at panicle initiation stage. However, nitrogen application at $1 / 2 \mathrm{~N}$ basal $+1 / 4 \mathrm{~N}$ at active tillering stage $+1 / 4 \mathrm{~N}$ at panicle initiation stage had minimum weed control efficiency than other nitrogen treatments due to higher dry weight of weeds. Same results were given by Singh et al., (2005).

Among various weed management practices, two hand weedings at 20 and 40 DAS recorded higher weed control efficiency than other weed management practices which might be due to lower weed dry matter accumulation. The result find ample support from the findings of Murthy et al., (2012). Followed by application of bispyribac at $25 \mathrm{~g}$ a.i. ha ${ }^{-1}+$ azimsulfuron at $17.5 \mathrm{~g}$ a.i. $\mathrm{ha}^{-1}+$ NIS $(0.25 \%)$ at $15-20$ DAS and bispyribac at $25 \mathrm{~g}$ a.i. $\mathrm{ha}^{-1}+$ pyrazosulfuron at $20 \mathrm{~g}$ a.i. $\mathrm{ha}^{-1}$ + NIS $(0.25 \%)$ at $15-20$ DAS recorded highest weed control efficiency during both the years.

This might be due to lower weed dry matter accumulation under these treatments and effective control of complex weed flora i.e grasses, sedges and broad leaved weeds. Tank mix application of herbicides controls wide spectrum of weeds effectively compared to sequential application of single herbicides. These results were in conformity with the findings of Ghosh et al., (2017).

\section{Effect on crop growth}

Plant population was not affected due to application of different nitrogen schedule. Significantly taller plant and maximum dry matter accumulation $25 \mathrm{~cm}^{-1}$ row length were recorded under nitrogen application of $1 / 4 \mathrm{~N}$ at basal $+1 / 4 \mathrm{~N}$ at active tillering stage $+1 / 4 \mathrm{~N}$ at panicle initiation stage $+1 / 4 \mathrm{~N}$ at heading stage which was at par with application of $1 / 3 \mathrm{~N}$ at basal $+1 / 3 \mathrm{~N}$ at active tillering stage $+1 / 3 \mathrm{~N}$ at panicle initiation stage than other nitrogen management treatments during both the years of experimentation (Table 2). 
Table.1 Effect of nitrogen and weed management practices on density of weeds, dry weight and WCE at 60 DAS of direct seeded rice

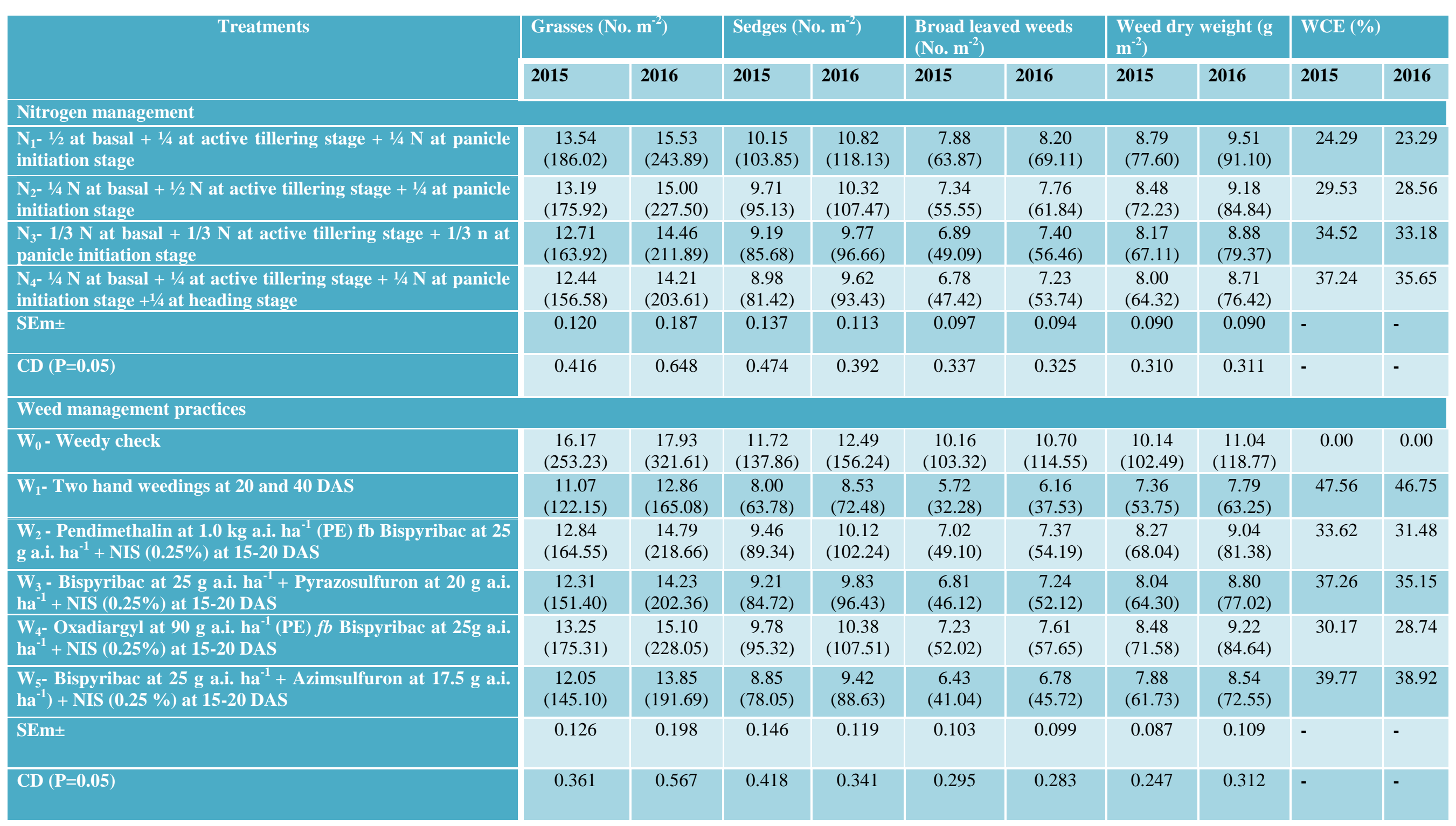


Table.2 Effect of nitrogen and weed management practices on crop growth characters in direct seeded rice

\begin{tabular}{|c|c|c|c|c|c|c|c|c|}
\hline \multirow[t]{2}{*}{ Treatments } & \multicolumn{2}{|c|}{$\begin{array}{l}\text { Plant population } \\
\text { at } 20 \text { DAS (no. } \mathrm{m}^{-} \\
2 \text { ) }\end{array}$} & \multicolumn{2}{|c|}{$\begin{array}{l}\text { Plant height } \\
(\mathrm{cm})\end{array}$} & \multicolumn{2}{|c|}{$\begin{array}{l}\text { Number of tillers } \\
\left(\mathrm{m}^{-1} \text { row length }\right)\end{array}$} & \multicolumn{2}{|c|}{$\begin{array}{l}\text { Dry matter } \\
\text { production (g/ } 25 \\
\text { cm row length) }\end{array}$} \\
\hline & 2015 & 2016 & 2015 & 2016 & 2015 & 2016 & 2015 & 2016 \\
\hline \multicolumn{9}{|l|}{ Nitrogen management } \\
\hline $\begin{array}{l}\mathrm{N}_{1}-1 / 2 \text { at basal }+1 / 4 \text { at active tillering stage }+1 / 4 \mathrm{~N} \text { at panicle } \\
\text { initiation stage }\end{array}$ & 41.67 & 39.21 & 85.00 & 82.39 & 57.87 & 56.16 & 57.87 & 54.99 \\
\hline $\begin{array}{l}\mathbf{N}_{2^{-}}-1 / 4 \mathrm{~N} \text { at basal }+1 / 2 \mathrm{~N} \text { at active tillering stage }+1 / 4 \text { at } \\
\text { panicle initiation stage }\end{array}$ & 42.26 & 39.81 & 89.50 & 87.22 & 61.63 & 60.21 & 61.29 & 59.65 \\
\hline $\begin{array}{l}\mathrm{N}_{3}-1 / 3 \mathrm{~N} \text { at basal }+1 / 3 \mathrm{~N} \text { at active tillering stage }+1 / 3 \mathrm{n} \text { at } \\
\text { panicle initiation stage }\end{array}$ & 43.27 & 41.22 & 91.58 & 89.11 & 65.55 & 63.01 & 63.04 & 60.44 \\
\hline $\begin{array}{l}\mathbf{N}_{4^{-}}-1 / 4 \mathrm{~N} \text { at basal }+1 / 4 \text { at active tillering stage }+1 / 4 \mathbf{N} \text { at } \\
\text { panicle initiation stage }+1 / 4 \text { at heading stage }\end{array}$ & 45.57 & 42.81 & 97.85 & 95.15 & 66.97 & 65.75 & 64.59 & 62.47 \\
\hline SEm \pm & 0.98 & 1.00 & 1.80 & 2.08 & 1.74 & 1.55 & 1.68 & 1.17 \\
\hline $\mathrm{CD}(\mathrm{P}=\mathbf{0 . 0 5})$ & NS & NS & 6.24 & 7.18 & 6.03 & 5.36 & 5.83 & 4.03 \\
\hline \multicolumn{9}{|l|}{ Weed management practices } \\
\hline $\mathrm{W}_{0}$ - Weedy check & 36.11 & 33.55 & 78.64 & 77.50 & 50.06 & 48.63 & 45.45 & 43.45 \\
\hline $\mathrm{W}_{1^{-}}$Two hand weedings at 20 and 40 DAS & 46.63 & 43.78 & 98.75 & 94.08 & 71.19 & 68.85 & 72.57 & 70.36 \\
\hline $\begin{array}{l}\mathrm{W}_{2} \text { - Pendimethalin at } 1.0 \mathrm{~kg} \text { a.i. } \mathrm{ha}^{-1} \text { (PE) fb Bispyribac at } \\
25 \text { g a.i. } \mathrm{ha}^{-1}+\text { NIS }(0.25 \%) \text { at } 15-20 \text { DAS }\end{array}$ & 43.81 & 41.35 & 90.26 & 89.17 & 62.17 & 60.52 & 60.80 & 57.30 \\
\hline $\begin{array}{l}\mathrm{W}_{3}-\text { Bispyribac at } 25 \mathrm{~g} \text { a.i. ha }{ }^{-1}+\text { Pyrazosulfuron at } 20 \mathrm{~g} \\
\text { a.i. } \mathrm{ha}^{-1}+\text { NIS }(0.25 \%) \text { at 15-20 DAS }\end{array}$ & 44.59 & 42.55 & 93.00 & 90.81 & 65.12 & 63.54 & 65.37 & 62.95 \\
\hline $\begin{array}{l}\mathrm{W}_{4^{-}} \text {Oxadiargyl at } 90 \mathrm{~g} \text { a.i. } \mathrm{ha}^{-1}(\mathrm{PE}) \mathrm{fb} \text { Bispyribac at } 25 \mathrm{~g} \\
\text { a.i. } \mathrm{ha}^{-1}+\text { NIS }(0.25 \%) \text { at } 15-20 \text { DAS }\end{array}$ & 42.32 & 40.32 & 89.25 & 88.25 & 61.34 & 59.96 & 56.97 & 54.39 \\
\hline $\begin{array}{l}\mathrm{W}_{5^{-}} \text {Bispyribac at } 25 \mathrm{~g} \text { a.i. } \mathrm{ha}^{-1}+\text { Azimsulfuron at } 17.5 \mathrm{~g} \text { a.i. } \\
\left.\mathrm{ha}^{-1}\right)+ \text { NIS }(0.25 \%) \text { at } 15-20 \text { DAS }\end{array}$ & 45.68 & 43.12 & 96.24 & 91.00 & 68.16 & 66.21 & 69.03 & 67.87 \\
\hline SEm \pm & 0.96 & 1.01 & 1.43 & 1.54 & 1.38 & 1.40 & 1.33 & 1.21 \\
\hline $\mathrm{CD}(\mathrm{P}=0.05)$ & 2.75 & 2.89 & 4.07 & 4.39 & 3.95 & 4.01 & 3.81 & 3.45 \\
\hline
\end{tabular}


Table.3 Effect of nitrogen and weed management practices on Yield $\left(\mathrm{t} \mathrm{ha}^{-1}\right)$ in direct seeded rice

\begin{tabular}{|c|c|c|c|c|}
\hline \multirow[t]{2}{*}{ Treatments } & \multicolumn{2}{|c|}{ Grain yield (t/ha) } & \multicolumn{2}{|c|}{ Straw yield (t/ha) } \\
\hline & 2015 & 2016 & 2015 & 2016 \\
\hline \multicolumn{5}{|l|}{ Nitrogen management } \\
\hline $\begin{array}{l}\mathrm{N}_{1}-1 / 2 \mathrm{~N} \text { at basal }+1 / 4 \text { Nat active tillering stage }+1 / 4 \mathrm{~N} \text { at panicle } \\
\text { initiation stage }\end{array}$ & 3.65 & 3.30 & 5.53 & 5.25 \\
\hline $\begin{array}{l}\mathrm{N}_{2^{-}} 1 / 4 \mathrm{~N} \text { at basal }+1 / 2 \mathrm{~N} \text { at active tillering stage }+1 / 4 \mathrm{~N} \text { at panicle } \\
\text { initiation stage }\end{array}$ & 3.84 & 3.48 & 5.69 & 5.44 \\
\hline $\begin{array}{l}\mathrm{N}_{3^{-}}-1 / 3 \mathrm{~N} \text { at basal }+1 / 3 \mathrm{~N} \text { at active tillering stage }+1 / 3 \mathrm{~N} \text { at panicle } \\
\text { initiation stage }\end{array}$ & 3.99 & 3.62 & 6.03 & 5.74 \\
\hline $\begin{array}{l}\mathrm{N}_{4^{-}} 1 / 4 \mathrm{~N} \text { at basal }+1 / 4 \mathrm{~N} \text { at active tillering stage }+1 / 4 \mathrm{~N} \text { at panicle } \\
\text { initiation stage }+1 / 4 \mathrm{~N} \text { at heading stage }\end{array}$ & 4.09 & 3.77 & 6.14 & 5.87 \\
\hline SEm \pm & 0.08 & 0.09 & 0.10 & 0.11 \\
\hline $\mathrm{CD}(\mathrm{P}=0.05)$ & 0.29 & 0.31 & 0.33 & 0.37 \\
\hline \multicolumn{5}{|l|}{ Weed management practices } \\
\hline $\mathrm{W}_{0}$ - Weedy check & 1.97 & 1.70 & 3.32 & 2.99 \\
\hline $\mathrm{W}_{1^{-}}$Two hand weedings at 20 and 40 DAS & 4.77 & 4.38 & 6.90 & 6.61 \\
\hline $\begin{array}{l}\mathrm{W}_{2} \text { - Pendimethalin at } 1.0 \mathrm{~kg} \text { a.i. } \mathrm{ha}^{-1}(\mathrm{PE}) \text { fb Bispyribac at } 25 \mathrm{~g} \text { a.i. } \\
\mathrm{ha}^{-1}+\text { NIS }(0.25 \%) \text { at } 15-20 \text { DAS }\end{array}$ & 4.04 & 3.72 & 6.05 & 5.83 \\
\hline $\begin{array}{l}\text { W }_{3}-\text { Bispyribac at } 25 \mathrm{~g}_{\text {a.i. }} \mathrm{ha}^{-1}+\text { Pyrazosulfuron at } 20 \mathrm{~g}^{\text {a.i. }} \mathrm{ha}^{-1}+ \\
\text { NIS }(0.25 \%) \text { at } 15-20 \text { DAS }\end{array}$ & 4.36 & 3.91 & 6.17 & 5.98 \\
\hline $\begin{array}{l}\text { W }_{4^{-}} \text {Oxadiargyl at } 90 \mathrm{~g} \text { a.i. } \mathrm{ha}^{-1}(\mathrm{PE}) \mathrm{fb} \text { Bispyribac at } 25 \mathrm{~g} \text { a.i. } \mathrm{ha}^{-1}+ \\
\text { NIS }(0.25 \%) \text { at } 15-20 \text { DAS }\end{array}$ & 3.67 & 3.32 & 5.73 & 5.54 \\
\hline $\begin{array}{l}\left.\text { W }_{5^{-}} \text {Bispyribac at } 25 \mathrm{~g} \text { a.i. } \text { ha }^{-1}+\text { Azimsulfuron at } 17.5 \mathrm{~g} \text { a.i. } \mathrm{ha}^{-1}\right)+ \\
\text { NIS }(0.25 \%) \text { at } 15-20 \text { DAS }\end{array}$ & 4.56 & 4.21 & 6.72 & 6.40 \\
\hline SEm \pm & 0.13 & 0.15 & 0.15 & 0.13 \\
\hline $\mathrm{CD}(\mathrm{P}=0.05)$ & 0.36 & 0.42 & 0.44 & 0.37 \\
\hline
\end{tabular}


It was probably due to better availability of nitrogen at critical growth stages and also low weed infestation during these stage, resulting in favorable conditions for growth and development of crop. These results were in conformity with the findings of Kumar et al., (2015). The maximum number of tillers $\mathrm{m}^{-1}$ row length were recorded under nitrogen application of $1 / 4 \mathrm{~N}$ at basal $+1 / 4 \mathrm{~N}$ at active tillering stage $+1 / 4 \mathrm{~N}$ at panicle initiation stage $+1 / 4 \mathrm{~N}$ at heading stage might be due to ample space and nutrient available for emergence and growth of lateral shoots (tillers).

Amongst various weed management treatments, hand weeding twice at 20 and 40 DAS and the application of Bispyribac at $25 \mathrm{~g}$ a.i. $\mathrm{ha}^{-1}+$ Azimsulfuron at $17.5 \mathrm{~g}$ a.i. $\mathrm{ha}^{-1}+$ NIS $(0.25 \%)$ at $15-20$ DAS increased growth attributes like number of plant population $\mathrm{m}^{-1}$ row length, number of tillers $\mathrm{m}^{-1}$ row length and dry matter accumulation $25 \mathrm{~cm}^{-1}$ row length during both the years of experimentation. The weeds were controlled effectively under these treatments during both the years of experimentation. This could be attributed to higher weed control efficiency under these treatments. These findings are reported by Bhurer et al., (2013).

\section{Effect on crop yield}

Application of $1 / 4 \mathrm{~N}$ at basal $+1 / 4 \mathrm{~N}$ at active tillering stage $+1 / 4 \mathrm{~N}$ at panicle initiation stage $+1 / 4 \mathrm{~N}$ at heading stage was recorded maximum grain and straw yield followed by $1 / 3 \mathrm{~N}$ at basal $+1 / 3 \mathrm{~N}$ at active tillering stage $+1 / 3 \mathrm{~N}$ at panicle initiation stage than other nitrogen treatments and was on par to each other (Table 3). The increased grain and straw yield was perhaps the result of reduced weed density and their dry weight, better weed control efficiency. These findings were in conformity with the results of Kumawat et al., (2017). The minimum grain and straw yield was recorded under nitrogen application of $1 / 4$
$\mathrm{N}$ at basal $+1 / 2$ at $\mathrm{N}$ active tillering stage $+1 / 4$ $\mathrm{N}$ at panicle initiation stage and $1 / 2 \mathrm{~N}$ at basal $+1 / 4$ at $\mathrm{N}$ active tillering stage $+1 / 4 \mathrm{~N}$ at panicle initiation stage. Amongst various weed management treatments, hand weeding twice at 20 and 40 DAS and the application of Bispyribac at $25 \mathrm{~g}$ a.i. $\mathrm{ha}^{-1}+$ Azimsulfuron at $17.5 \mathrm{~g}$ a.i. $\mathrm{ha}^{-1}+\mathrm{NIS}(0.25 \%)$ at $15-20$ DAS resulted in significantly higher grain and straw yield (Table 3) than other weed management treatments. The increased yield in these treatments might be due to cumulative effect of lower weed density, dry weight, and higher weed control efficiency. The maximum grain and straw yield was recorded under Bispyribac at $25 \mathrm{~g}$ a.i. $\mathrm{ha}^{-1}+$ Azimsulfuron at $17.5 \mathrm{~g}$ a.i. $\mathrm{ha}^{-1}+$ NIS (0.25 $\%)$ at 15-20 DAS as given by Ghosh et al., (2017).

\section{References}

Amarjit, SB, Singh, M, Kachroo, D, Sharma, BC and Shrivan, DR, Efficacy of herbicides in transplanted medium duration rice (Oryza sativa) under subtropical conditions of Jammu, Indian Journal of Agronomy, 51(2), 128-130, 2006.

Angiras, NN, Effect of seed rate, intercultural and weed management in direct-seeded upland rice (Oryza sativa), Extended Summaries, Vol. 2. of the 2nd International Agronomy Congress, held during 26-30 November at New Delhi, India, 929-930, 2002.

Bhurer, KP, Yadav, DN, Ladha, JK, Thapa, RB and Pandey, KR, Effecacy of various herbicides to control weeds in dry direct seeded rice (Oryza sativa L), Global Journal of Biology, Agriculture and Health Science, 2(4), 205-212, 2013.

Chaudhary, SK, Jha, S and Sinha, NK, Influence of nitrogen and weed management practices on productivity 
and nutrient uptake of wet direct seeded rice, Oryza, 48(3), 222-225, 2011.

Ghosh, D, Singh, UP, Brahmachari, K, Singh, NK and Das, A, An integrated approach to weed management practices in directseeded rice under zero tilled rice-wheat cropping system, International Journal of Pest Management, 63(1), 37-46, 2017.

Kumar, S, Rana, SS, Chander, N, Ramesh, Mixed weed flora management by bispyribac-sodium in transplanted rice. Indian Journal of Weed Science, 45, 151-155, 2013.

Kumar, S, Singh, RK, Meena, RN and Singh, SP, Effect of nitrogen scheduling and weed management on weed density, growth and yield of direct-seeded rice (Oryza sativa L.), Research on Crops, 16(4), 643-652, 2015.

Kumawat, A, Seema, S, Kumar, D, Singh, S, Jinger, D, Bamboriya, SD and Verma, AK, Effect of irrigation scheduling and nitrogen application on yield, grain quality and soil microbial activities in direct-seeded rice. International Journal of Current Microbiology and Applied Sciences, 6(5), 2855-2860, 2017.

Raj, SK, Jose, N, Mathew, R and
Leenakumary, $\quad \mathrm{S}, \quad$ Chemical management of non-grassy weeds in direct-seeded rice, Indian Journal of Weed Science, 45(3), 159-162, 2013.

Singh, AP, Chowdhury, T, Kolhe, SS, Bhambri, MC and Chandrakar, BL, Weed shift and grain yield as influenced by tillage and weed management methods in rice-wheat cropping system in Chattisgarh, Indian Journal of Weed Science, 42(1\&2), 31-36, 2010.

Singh, MK and Singh, A, Effect of stale seedbed method and weed management on growth and yield of irrigated directseeded rice, Indian Journal of Weed Science, 44(3), 176-180, 2012.

Singh, RP, Singh, CM and Singh, AK, Effect of crop establishment method, weed management and split application of nitrogen on weeds and yield of rice (Oryza sativa), Indian Journal of Agricultural Sciences, 75(5), 285-287, 2005.

Walia, US, Bhullar, MS, Nayyar, S, Walia, SS, Control of complex weed flora of dry seeded rice (Oryza sativa L.) with pre- and post-emergence herbicides, Indian Journal of Weed Science, 40, 161-164, 2008.

\section{How to cite this article:}

Bonu Rama Devi and Yashwant Singh. 2018. Influence of Nitrogen and Weed Management Practices on Growth and Yield of Direct Seeded Rice (Oryza sativa L.). Int.J.Curr.Microbiol.App.Sci. 7(01): 2566-2574. doi: https://doi.org/10.20546/ijcmas.2018.701.309 